\title{
Geothermal activity in the subglacial Katla caldera, Iceland, 1999-2005, studied with radar altimetry
}

\author{
Magnús T. GUĐMUNDSSON, ${ }^{1}$ Pórdís HÖGNADÓTTIR, ${ }^{1}$ \\ Arnór Bergur KRISTINSSON, ${ }^{2}$ Snæbjörn GUĐBJÖRNSSON ${ }^{2}$ \\ ${ }^{1}$ Institute of Earth Sciences, University of Iceland, Sturlugata 7, IS-101 Reykjavik, Iceland \\ E-mail: mtg@raunvis.hi.is \\ ${ }^{2}$ Icelandic Civil Aviation Administration, Reykjavik Airport, IS-101 Reykjavik, Iceland
}

\begin{abstract}
The Katla caldera is located under the Mýrdalsjökull ice cap and is one of the most hazardous volcanoes in Iceland due to major jökulhlaups that accompany eruptions. Subglacial geothermal activity is manifested in several $10-50 \mathrm{~m}$ deep depressions (ice cauldrons) within and at the caldera rim and the total geothermal heat output is of the order of a few hundred megawatts. A shortlived but powerful pulse in geothermal heat output took place in 1999, probably including a minor subglacial eruption, when new ice cauldrons formed in three places and an unexpected jökulhlaup occurred. Following these events, a comprehensive monitoring program was set up for Katla, including ice surface elevation profiling from aircraft, to monitor variations in geothermal heat and detect signs of subglacial water accumulation. A radar altimeter coupled with a kinematic GPS is used, achieving an absolute elevation accuracy of $3 \mathrm{~m}$ and internal consistency of 1-2 $\mathrm{m}$. Profiles across the caldera are flown twice a year. An annual accumulation-ablation cycle in surface elevation with amplitude of $5-10 \mathrm{~m}$ is observed. By removing this cycle from the data, changes due to subglacial geothermal activity are obtained. After the events in 1999, a decline in geothermal activity was observed. In 2001-03 some ice cauldrons expanded and deepened by 10-15 m, indicating renewed increase in geothermal activity. This trend is also apparent for 2003-05. The increase in geothermal power amounts to a few tens of megawatts. It is likely that the increased thermal output is related to increased seismicity and caused by magma inflow.
\end{abstract}

\section{INTRODUCTION}

Geothermal and volcanic activity in glaciated regions is manifested by depressions in the ice surface, formed by enhanced basal melting. Beneath these depressions, water may accumulate, later to be released in jökulhlaups. Flooding of this nature can be a significant hazard to inhabited regions in the vicinity of ice-covered volcanoes. Jökulhlaups caused by the release of volcanic or geothermal heat under ice occur in several regions around the world (e.g. Major and Newhall, 1989; Pierson and others, 1990). In Iceland, the subglacial volcanoes of Grímsvötn in Vatnajökull and Katla
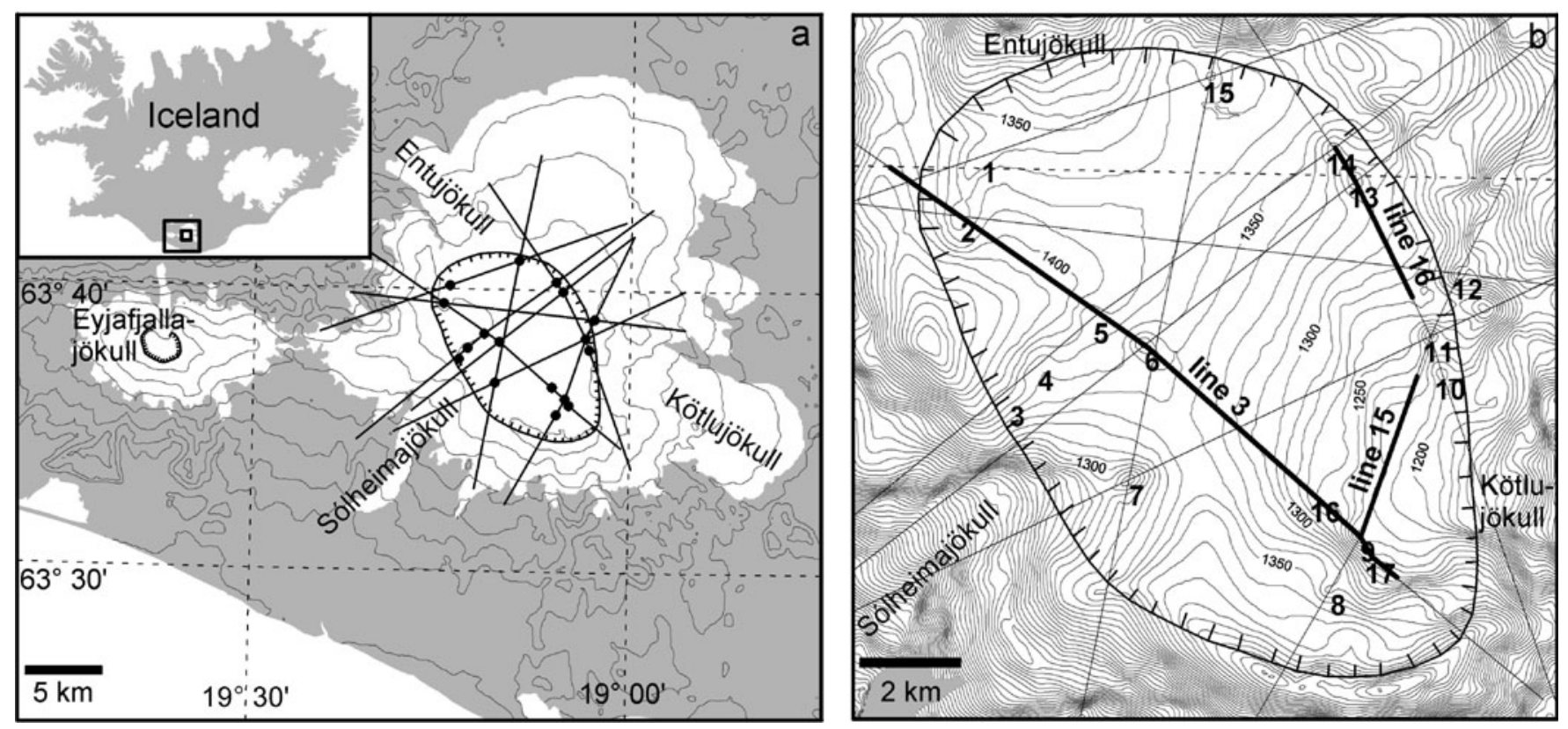

Fig. 1. (a) Map of Mýrdalsjökull with the Katla caldera and the neighbouring Eyjafjallajökull ice cap. The radar altimetry survey lines flown in spring and autumn to monitor ice cauldrons are indicated. (b) Map of the Katla caldera with ice cauldrons 1-17. 


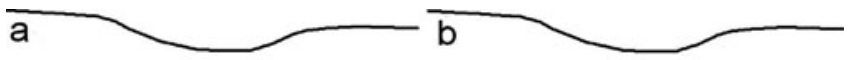

ice

ice

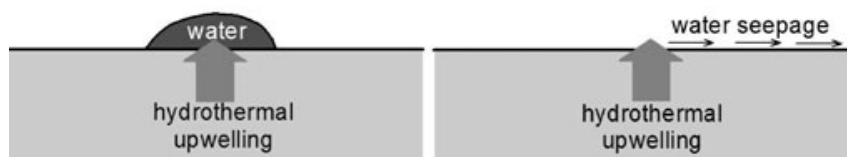

Fig. 2. Schematic sections showing the relation between ice cauldrons and underlying geothermal areas. (a) Cauldron with water accumulation, and (b) cauldron with continuous drainage.

in Mýrdalsjökull are renowned for being sources of jökulhlaups of geothermal and volcanic origin (e.g. Thorarinsson, 1974; Tómasson, 1996; Larsen, 2000; Björnsson, 2002).

Katla, with its $100 \mathrm{~km}^{2}$ caldera (Fig. 1) filled with 400 $700 \mathrm{~m}$ thick ice (Björnsson and others, 2000), is one of the most dangerous volcanoes in Iceland because of its proximity to inhabited areas. Eruptions produce swift and often catastrophic jökulhlaups that over the last 1100 years have drained to the east over the outwash plain of Mýrdalssandur (e.g. Larsen, 2000). Twenty-two eruptions are known to have breached the surface and created tephra layers over the last 1200 years (Elíasson and others, 2006). In addition, minor, fully subglacial eruptions may have occurred. Such minor eruptions are suspected to be responsible for ice cauldron formation accompanied with sudden jökulhlaups in 1955 and 1999 (e.g. Tryggvason, 1960; Guðmundsson, 2005).

Following an unexpected and sudden jökulhlaup in July 1999 and signs of increased geothermal activity, a comprehensive monitoring system was set up around Katla, since these signs were interpreted as an increased risk of eruption. The monitoring system is jointly run by the Icelandic Meteorological Office, the Hydrology Department of the National Energy Authority and the Institute of Earth Sciences, University of Iceland. It consists of enhanced seismic surveillance, continuous GPS monitoring of ground deformation, automatic gauging stations in rivers and regular ice surface profiling to monitor ice cauldrons and their potential for subglacial water storage. In this paper we outline the methods used to monitor the ice cauldrons, describe the geothermal activity within the Katla caldera and discuss the implications of these results for Katla.

\section{ICE CAULDRONS}

The term ice cauldron has been used for depressions on the surface of glaciers caused by enhanced and localized heat flux from the bedrock (Björnsson, 1975). The size of ice cauldrons varies but most cauldrons are roughly circular or elliptic in shape. Cauldrons, sustained by subglacial hydrothermal upwelling may be semi-permanent or they may be transient features that persist for a few years. The largest cauldrons in Iceland are the Skaftár Cauldrons in the western part of Vatnajökull with diameters of $2-3 \mathrm{~km}$ (Björnsson, 2002). Most cauldrons are smaller, including several within the drainage area of the Grímsvötn caldera in Vatnajökull (e.g. Björnsson and Guðmundsson, 1993), or the cauldrons within the Katla caldera. In common usage the term cauldron covers the spectrum from shallow, uncrevassed depressions to deep, steep-sided and highly crevassed

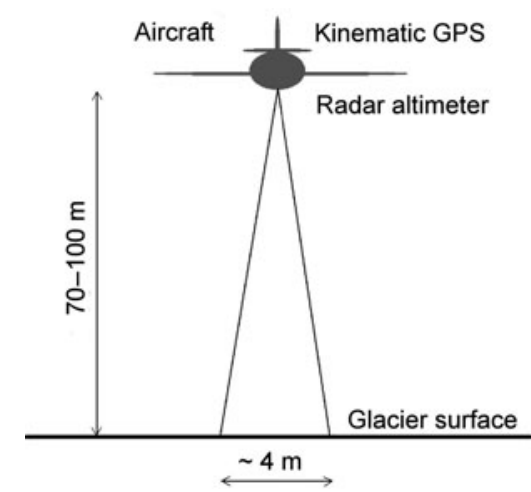

Fig. 3. Schematic setup of GPS and radar altimeter. The footprint indicated is the width of the first Fresnel zone.

chasms. Meltwater is accumulated under many cauldrons for some periods before it is released in jökulhlaups (Fig. 2a). Some of the smaller cauldrons do not display any obvious changes in surface geometry over extended periods and seem not to collect water or release it in an episodic manner (Fig. 2b). Meltwater from these cauldrons apparently seeps away continuously without water accumulation. Both types occur within the Katla caldera.

The total heat output of the geothermal areas within the Katla caldera has not been measured but an order of magnitude estimate can be obtained from mass balance considerations. Limited mass balance measurements (Eythorsson, 1945; Rist, 1957; Institute of Earth Sciences, unpublished data, 2001) indicate that the winter mass balance in the caldera is on average $5-7 \mathrm{~m} \mathrm{a}^{-1}$ water equivalent (w.e.). Observations from 2001 (Institute of Earth Sciences, unpublished data) and comparison with measurements for the same elevation span at Vatnajökull (Björnsson and others, 2002) indicate a negative summer balance of $2-3 \mathrm{ma}^{-1}$ w.e. Thus, the average net balance for the Katla caldera is considered to be in the range $2-4 \mathrm{~m} \mathrm{a}^{-1}$ w.e. and the total annual balance in the $100 \mathrm{~km}^{2}$ caldera is expected to be $0.2-0.4 \mathrm{~km}^{3} \mathrm{a}^{-1}$ w.e. Most of this ice flows out of the caldera down the outlet glaciers. The order of magnitude of ice melted underneath the ice cauldrons is about $10 \%$ of the $0.2-0.4 \mathrm{~km}^{3} \mathrm{a}^{-1}$ w.e. Using calorimetry, with the latent heat of fusion for ice $L_{\mathrm{i}}=3.35 \times 10^{5} \mathrm{~J} \mathrm{~kg}^{-1}$ and water density $\rho=1000 \mathrm{~kg} \mathrm{~m}^{-3}$, the annual heat output required to melt $0.02-0.04 \mathrm{~km}^{3} \mathrm{a}^{-1}$ w.e. would be $200-400 \mathrm{MW}$. This value is highly uncertain but indicates that the long-term heat output of the geothermal areas within the Katla caldera is of the order of few hundred megawatts.

\section{SURVEYING SYSTEM}

The successful use of a radar altimeter coupled with GPS positioning of aircraft during the Gjálp eruption in Vatnajökull, Iceland in 1996 (Guðmundsson and others, 1997; 2004) revealed the potential of this relatively simple and inexpensive method to obtain quantitative data on ice surface elevation changes. In the present system, the ice surface profiling is carried out by recording simultaneously the kinematic GPS position and flight elevation using a radar-altimeter (Fig. 3) aboard the aircraft of the Icelandic Civil Aviation Administration.

The radar-altimeter is an analogue Collins ALT-50, operating at $4300 \mathrm{MHz}$ with an error of $2 \%$. This radar altimeter 

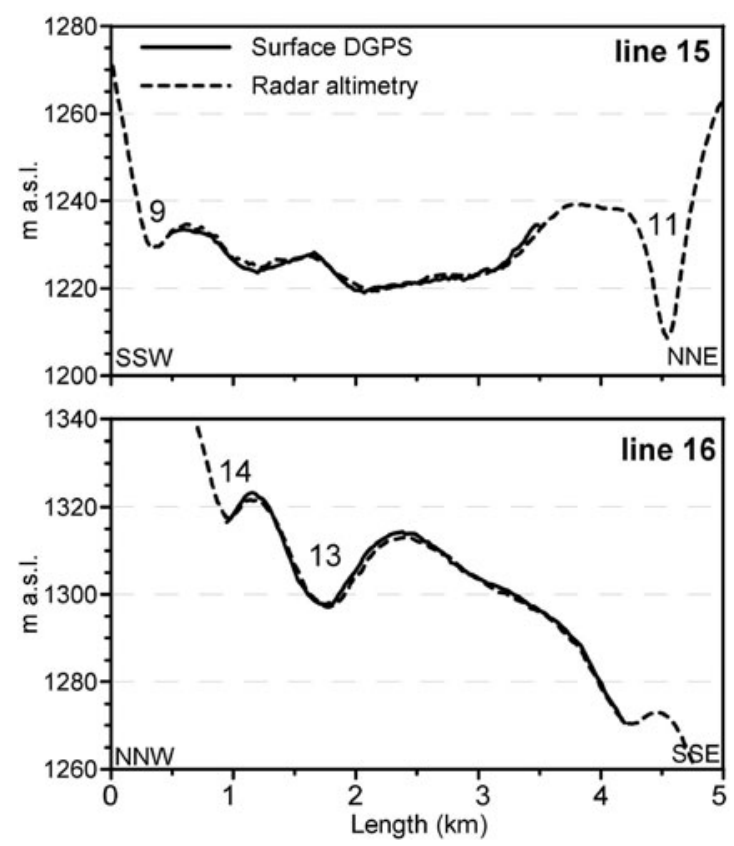

Fig. 4. Comparison of a radar altimeter survey on 14 September 2000 and a ground survey on 1 September in the same year.

was already installed in the aircraft and used as a low altitude elevation monitoring and terrain warning system and faces directly downwards. Dynamic range of the altimeter is 0-995 metres of height. Beam width is around $20^{\circ}$ of a conical shape. Therefore, in order to keep horizontal resolution and vertical accuracy within reasonable limits, the aircraft is flown at $70-100 \mathrm{~m}$ above the glacier surface. The altitude measured by the radar is corrected by software with two linear functions of the first order. These linear models were developed on data derived from an airborne data adjustment campaign with test flights over sea, land and icy surfaces. The radar footprint is a circle of around $15 \mathrm{~m}$ radius for these nominal altitudes, and the radar measures the first viable response (the highest ground). In this respect it can be theorized that the limit of horizontal radar resolution of the first response can be determined from the width of the first Fresnel zone $d$, given by $d=(h \lambda / 2)^{1 / 2}$, where $h$ is height above the target (glacier surface) and $\lambda=7 \mathrm{~cm}$ is the wavelength in question. For our nominal flying heights this would then be a footprint of $d=3.5-4 \mathrm{~m}$. Thus, the accuracy of the aeroplane height relative to the glacier surface is about $2 \mathrm{~m}$ when flying in the expected areas of low surface slope. Actual measurements confirm this theory, as described below.

The accuracy of the kinematic GPS is estimated within $1 \mathrm{~m}$, yielding a total estimated error in measured height of around $2-3 \mathrm{~m}$ for the baseline lengths in question. The surveys are conducted using the WGS84 geodetic reference system and the NKG96 geoid for conversion of GPS-derived height above ellipsoid to height above sea level. The reference station is usually set up in Reykjavik, which is some $150-200 \mathrm{~km}$ away from the areas of interest. The manufacturer of the GPS system used gives an accuracy error of $1 \mathrm{~mm}+1 \mathrm{ppm}$ (parts per million) per given baseline resulting in around $20 \mathrm{~cm}$ theoretical accuracy. On the other hand, the length of the baselines cause an increase in error because of the different view to the satellites in the GPS constellation, resulting in the aforementioned accuracy estimate of just under $1 \mathrm{~m}$. The GPS gives a position once every second, while the ground clearance is measured 4 times a second. Typical aircraft velocity is $70-80 \mathrm{~m} \mathrm{~s}^{-1}$ implying that a sounding of the glacier surface occurs at 17$20 \mathrm{~m}$ intervals along the flight line. Accurate time, based on GPS satellite constellation time from the GPS receiver, together with the altimeter readings (digitized through an AD converter) are sampled onto a laptop PC. After postprocessing of the GPS positions, the coordinates of the three intermediate elevation sounding points are obtained by linear interpolation of the 1 second GPS coordinates.

The internal consistency of the airborne elevation soundings was tested on analysis of the amount of intersection in 54 crossover points on Mýrdalsjökull. The mean waypoint error obtained was $1.2 \mathrm{~m}$. Traverses of the same lines between waypoints with the airborne radar altimeter system have been compared to DGPS positions collected by a snowmobile travelling the same lines on the glacier surface in September 2000 (Fig. 4). The Trimble ${ }^{\circledR}$ Pathfinder submetre DGPS system used for the snowmobile traverses has been shown to yield a horizontal error less than $1 \mathrm{~m}$ and a vertical error less than $2 \mathrm{~m}$ for baseline lengths of 50-100 km, as used for this survey (Guðmundsson and others, 2002). The results show that where the flight line and the snowmobile track coincide, the standard deviation of the difference between the two elevations is $0.9 \mathrm{~m}$. Thus, provided aircraft height above ground is not significantly greater than $100 \mathrm{~m}$ we conclude that the system has an absolute accuracy cautiously estimated as $3 \mathrm{~m}$, and an internal consistency of $1-2 \mathrm{~m}$. This accuracy is achieved in calm weather with good visibility. If surveying is carried out during windy conditions, irregular tilting of the aircraft will lead to deviations from the vertical and increased pilot corrections to the aircraft flight produce noisier data. Relatively calm days are therefore selected for surveying for a better match with the test set used to authenticate the relative accuracy of the method.

\section{CAULDRON SURVEYING}

The first soundings with the GPS radar-altimeter system took place in October 1999. Two flights have been flown annually, one in spring and another in autumn, but more frequent flights took place during the first year of surveying. The nine survey lines within the caldera are strategically positioned to cross all known ice cauldrons (Fig. 1) with the majority crossed by only two survey lines. In addition, there are surveyed flight tracks down the central flow lines of the three main outlet glaciers of the caldera and the northern lobe of Mýrdalsjökull, which are surveyed once a year. These data have been used to estimate the effect on crustal deformation of seasonal ice loading and shrinkage since 1999 (Pinel and others, 2007).

In order to better track ice cauldron variability and other ice surface changes, visual inspection flights are carried out from a light aircraft by a local pilot about once a month. Photographs from these flights provide useful additional information on cauldron development (Fig. 5).

\section{THERMAL EVENTS}

In mid-July 1999, minor seismic activity took place in the centre of the Katla caldera with distinct bursts of seismic tremor occurring in the afternoon and evening of 17 July (Einarsson, 2000). In the early morning of 18 July, a swift 
jökulhlaup emerged from Sólheimajökull, the southern outlet of Mýrdalsjökull. It reached a peak discharge of $1700 \mathrm{~m}^{3} \mathrm{~s}^{-1}$ at a bridge $4 \mathrm{~km}$ from the glacier edge and had a floodwater volume of $(18 \pm 3) \times 10^{6} \mathrm{~m}^{3}$ (Sigurðsson and others, 2000). Aerial inspection on 18 July revealed that an ice cauldron $1-1.5 \mathrm{~km}$ in diameter and $40-50 \mathrm{~m}$ deep (Fig. 5a) had formed in the drainage area of Sólheimajökull (cauldron 7 in Fig. 1). The volume of the cauldron was $(20 \pm 4) \times 10^{6} \mathrm{~m}^{3}$. Its formation has been attributed to a minor subglacial eruption (Einarsson, 2000).

The ice surface and bedrock of Mýrdalsjökull was measured with radio-echo soundings in 1991 by Björnsson and others (2000), who presented a map of the fluid potential based on bedrock and surface geometry. The area of cauldron 7 was well covered, since it was traversed by radio-echo survey lines with a spacing of only $500 \mathrm{~m}$, similar to the ice thickness at this site. The data indicate that conditions for storage of water at this locality did not exist. Thus, water accumulation for any appreciable period prior to the event is unlikely. This indicates that the meltwater was generated quickly, which supports the suggestion of a minor subglacial eruption.

Using calorimetry, with $L_{\mathrm{i}}=3.35 \times 10^{5} \mathrm{~J} \mathrm{~kg}^{-1}$ as before and ice density of $\rho=910 \mathrm{~kg} \mathrm{~m}^{-3}$, the energy required to melt the cauldron is $E=\rho V L_{\mathrm{i}}=6 \times 10^{15} \mathrm{~J}$. It is unclear how fast the water that drained from this area was created by ice melting. If this was melted over 3 days (15-17 July, the period of slight change in earthquake activity within the caldera), the average power required is $2.4 \times 10^{10} \mathrm{~W}$. Judging from the size of the cauldron, the area of elevated heat flux was no larger than $\sim 1 \mathrm{~km}^{2}$. Thus, the heat flux would have been $2-3 \times 10^{4} \mathrm{~W} \mathrm{~m}^{-2}$. This is of the right order for eruption of pillow lavas (Höskuldsson and Sparks, 1997; Guðmundsson, 2003). Alternatively, if all the melting took place during a few hours in the evening of 17 July, the power would have been an order of magnitude higher, and the corresponding heat flux similar to that observed for vigorous explosive eruptions with magma fragmentation in water (Guðmundsson, 2003; Guðmundsson and others, 2004).

In the weeks following the 18 July jökulhlaup, two new cauldrons formed (8 and 15) and fresh crevasses around the periphery of some of the other cauldrons suggest that they also deepened. Data on exact size and depth of cauldrons before the July events are not available. A minimum estimate of the thermal output associated with this later phase of the 1999 events is obtained from the energy required to form cauldrons 8 and 15. Although only being a qualitative indication, vertical aerial photographs taken on 8 August of the whole ice cap indicate that these two cauldrons had largely reached their full size by then. On 8 October, when the first radar-altimetry profiling was carried out, cauldrons 8 and 15 were already fully developed. The volume of ice melted during the formation of cauldrons 8 and 15 is $(3.8 \pm 0.5) \times 10^{6} \mathrm{~m}^{-3}$, requiring $1.2 \times 10^{15} \mathrm{~J}$ of thermal energy. If this energy was released over 22 days ( 17 July8 August) the heat output was equivalent to $630 \mathrm{MW}$. If the heat release is taken as having occurred over an $\sim 80$ day period (late July-early October), the increased heat output was $170 \mathrm{MW}$.

In summary, the 1999 thermal event was highly unusual for Katla, with very rapid melting leading to the formation of a new ice cauldron apparently over a few hours or days in July 1999. More gradual heat release in the weeks that followed led to the formation of two more cauldrons. During these
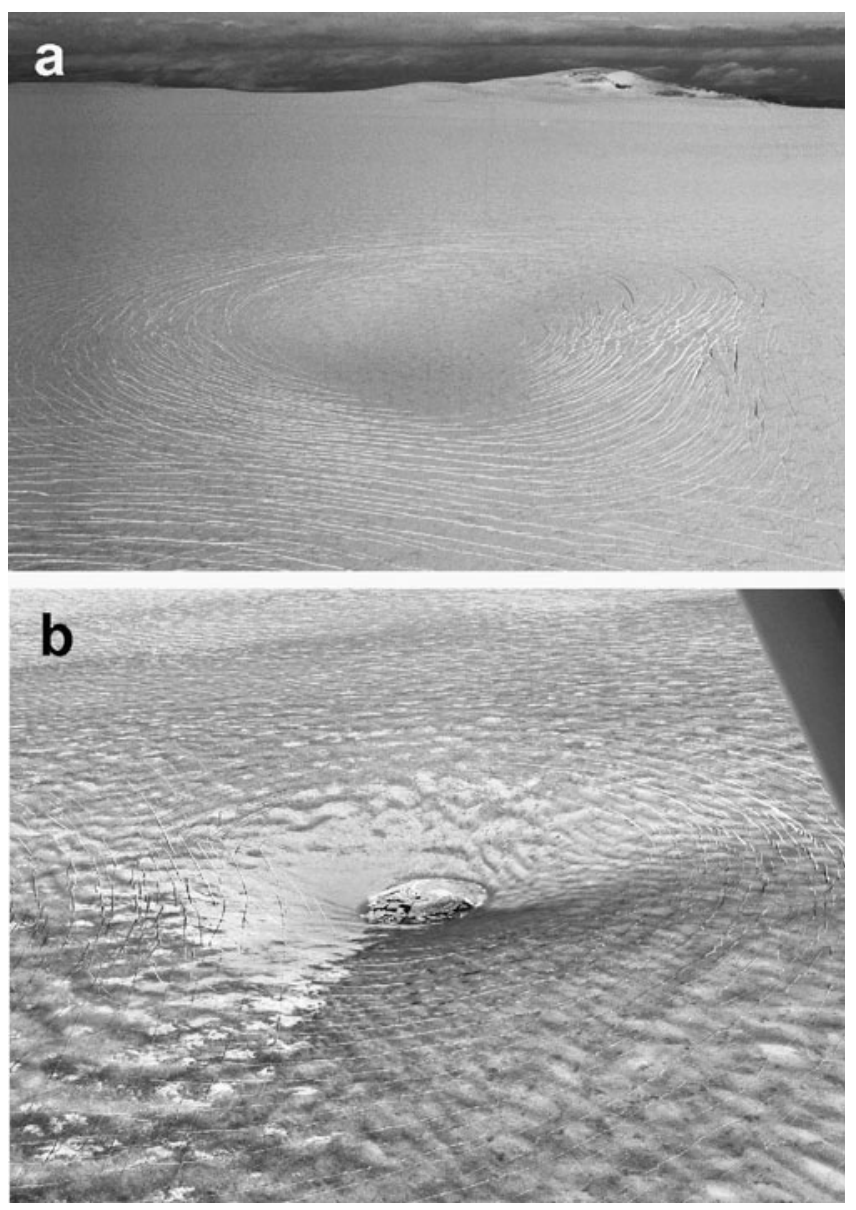

Fig. 5. (a) The ice cauldron (no. 7) formed on 18 July 1999. Photograph taken in August 1999. (b) Cauldron 11 in July 2005. Fresh crevasses indicate recent subglacial drainage. Surface ablation forms a water pool at the bottom of the cauldron (photograph: Reynir Ragnarsson).

events, the thermal output of the caldera was apparently increased by 2 orders of magnitude for a brief period around 17 July, and for some weeks afterwards the heat output was roughly doubled compared to the long-term average.

A similar event occurred in June 1955, when a jökulhlaup of about the same size as in 1999 burst from underneath Kötlujökull, the eastern outlet glacier of the caldera (Fig. 1). At that time cauldrons 10 and 11 either formed or grew significantly (Thorarinsson, 1957). Tryggvason (1960) proposed that the cause of the 1955 jökulhlaup was a minor subglacial eruption.

\section{GEOTHERMAL ACTIVITY 1999-2005}

Our data show that surface elevation within the Katla caldera varies by several metres between spring and autumn. Figure 6 shows a NW-SE profile across the caldera in 13 May and 8 October 2003. The difference in surface elevation is $8-10 \mathrm{~m}$, but greater in cauldron 16 . We use the changes in the depth of cauldrons relative to their surroundings as an indicator of variations in geothermal activity.

Most cauldrons show only moderate variations. Figure 7 shows the evolution of six cauldrons: no. 6, 7, 8, 11, 15 and 16 (see Fig. 1b for location). The figure shows the constant decline of cauldron 7 since its formation in 1999. Cauldron 8 formed in July-September 1999. It had already started to 


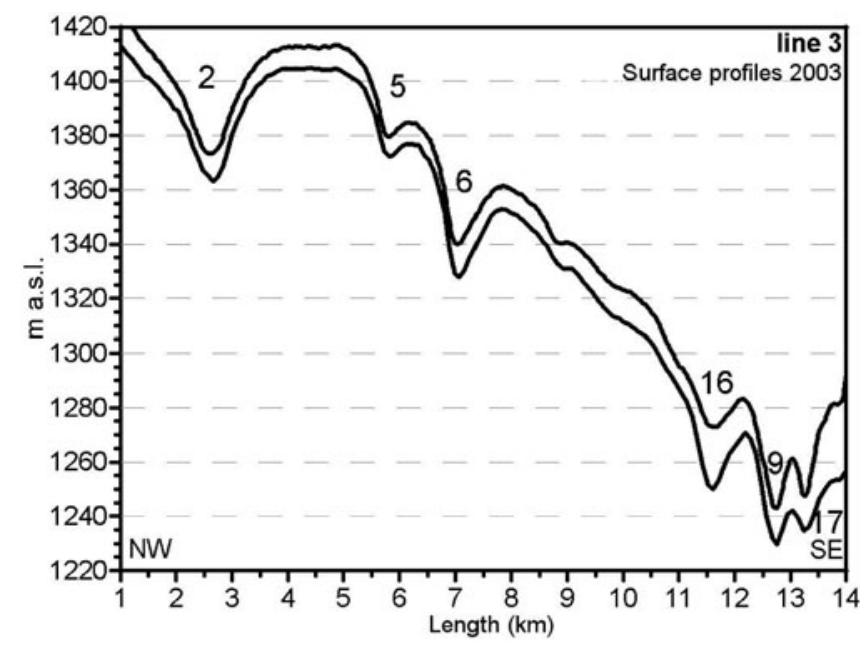

Fig. 6. Survey line 3 flown from northwest to southeast across the caldera, crossing cauldrons 2, 5, 6, 16 and 9 in 2003. Upper surface: spring; lower surface: autumn.

decline in October 1999, and could no longer be detected by the end of 2001. In contrast, cauldron 15 which also formed in July-September 1999 has had a more complex history. Its depth first declined, then it increased again (2001-03) followed by a minor decline (2003-05).

The lower panel on Figure 7 shows an example of a cauldron (no. 16) that increased in size in 2001-03. Cauldron 6 has been stable throughout the whole period while the trend of cauldron 11 is towards greater depth.

Cauldrons 11 and 16 are usually $5-15 \mathrm{~m}$ deeper in autumn than in spring. Visual inspection shows that concentric crevasses usually appear in these cauldrons during summer (Fig. 5b). This behaviour indicates water accumulation in winter followed by subsidence and drainage in summer. Small jökulhlaups, detected as an increase in electrical conductivity and water level, are frequent in river Múlakvísl which drains Kötlujökull, the main outlet of the caldera (National Energy Authority, web page on river monitoring: http://www.os.is). Cauldrons 11 and 16 have diameters of $800-1000 \mathrm{~m}$ and if it is assumed that a $10 \mathrm{~m}$ high cone-shaped water body forms in winter, the drainage of each of these cauldrons should lead to a jökulhlaup of volume $0.5-1.0 \times 10^{6} \mathrm{~m}^{3}$. If a jökulhlaup draining a reservoir of this size lasts several hours, the mean discharge would be $10-100 \mathrm{~m}^{3} \mathrm{~s}^{-1}$, which is the right magnitude for the minor events observed every summer. Similar small jökulhlaups occasionally drain towards northwest, emerging from underneath Entujökull. Cauldrons 1 and 2 are located in the drainage area of Entujökull but our data have not shown seasonal variations in these cauldrons. This also holds for the majority of other ice cauldrons in Katla.

A qualitative measure of geothermal activity within the Katla caldera is provided by our ice cauldron data. We classify the cauldrons into three types: declining, stable and expanding. A declining cauldron is one where the depth has decreased by more than $5 \mathrm{~m}$. Fluctuations that last only a few months, if present, do not register since a change has to be confirmed by two consecutive surveys, which are usually carried out at an interval of 5-7 months. An expanding cauldron is one where the depth has increased by more than $5 \mathrm{~m}$. The survey period 1999-2005 is split into three equally long intervals on Figure 8. In the first interval, 1999-2001,

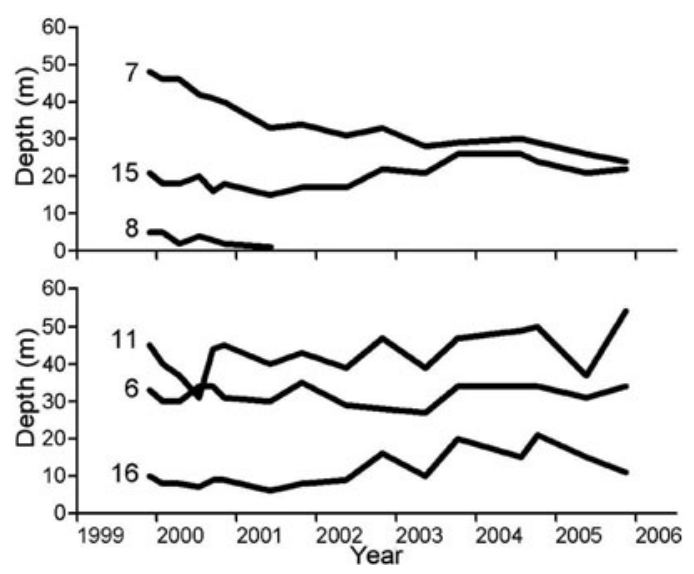

Fig. 7. Depth variations of cauldrons 6, 7, 8, 11, 15 and 16 in 19992005. Depth is measured relative to surrounding ice surface, which should compensate for effects of seasonal surface melting.

after the thermal pulse in the summer of 1999, geothermal activity is decreasing with six cauldrons declining and only one cauldron expanding. A change occurs in 2001-03 when three cauldrons (10, 15 and 16) expanded as the depth of each increased by $10-15 \mathrm{~m}$. For the third interval, 2003-05, the increase of 16 is halted while 10 and 15 experience some decrease. However, most cauldrons in the northern and western part of the caldera are expanding, but at a slower rate than observed in 2001-03.

An estimate of the minimum increase in heat output in 2001-03 is obtained through calorimetry. Cauldron 10 has a diameter of $800 \mathrm{~m}$ and a depth increase of $11 \mathrm{~m}$ occurred in 2001-03. The volume of ice melted in excess of that required to balance inflow and surface accumulation is $2 \times 10^{6} \mathrm{~m}^{3}$. Since this change occurred over two years, the increase in heat output required is $10 \mathrm{MW}$. The corresponding values for cauldrons 15 and 16 are $17 \mathrm{MW}$ and $13 \mathrm{MW}$. These numbers are systematically biased towards low values since they do not take into account a likely increase in ice inflow towards the cauldrons. Thus, the minimum increase in geothermal activity in 2001-03 was somewhat greater than $40 \mathrm{MW}$. Although the number of expanding cauldrons increased in 2003-05, any increase in geothermal activity was slower, since the rates of increase were less than seen in the previous period.

\section{DISCUSSION}

Monitoring of the ice cauldrons in Katla has revealed patterns of geothermal activity that would be difficult to obtain for an ice-free geothermal area, unless very detailed, semi-continuous monitoring was applied. This is one of the advantages of the calorimetric approach, possible for icecovered areas.

The data show that cauldrons can form over a few weeks, requiring sudden onset of vigorous geothermal upwelling in the uppermost part of the crust. Such pulses can be shortlived, as witnessed by the decline of cauldron 8, which disappeared in 2 years. A possible cause for this kind of behaviour is a sudden influx of heat, such as might be achieved by a magmatic intrusion to shallow levels in the crust. Alternatively, faulting may lead to greatly enhanced permeability, exposing hot rock to groundwater and the onset of a geothermal convection cell. 

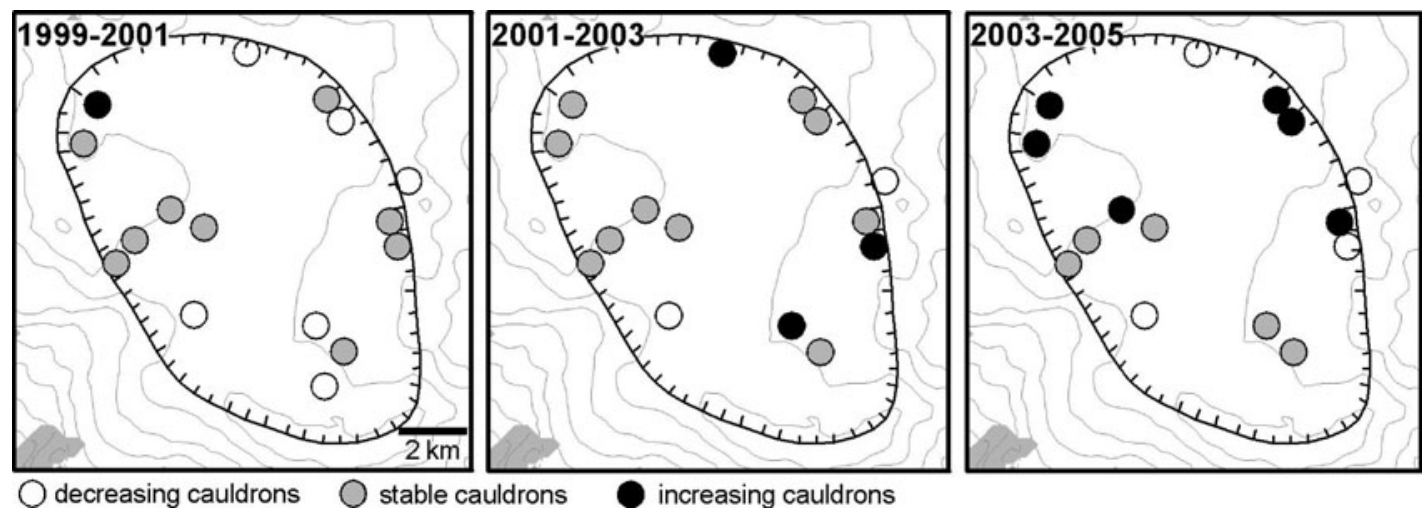

Fig. 8. Spatial and temporal variations in geothermal activity in 1999-2005 in the Katla caldera, according to cauldron depth variations.

The formation of cauldron 7 in July 1999 is an enigmatic event. It was suggested that the heat exchange leading to the formation of the meltwater occurred over a few hours or days. If that is the case, the only plausible explanation that can be reconciled with heat fluxes of $10^{4}-10^{5} \mathrm{~W} \mathrm{~m}^{-2}$ is eruption of magma to the base of the glacier. This would also explain the lack of any appreciable geothermal heating at the site in the years after the event; very effective heat mining of the volcanic material would quickly exhaust the magmatic heat.

The increase in geothermal heat output observed in 2001-03 occurred at the same time as seismic activity increased greatly and measurements of ground deformation showed steady inflation of the volcano (Sturkell and others, 2006). A common cause for these events would be magma accumulation in a magma chamber underneath the caldera as suggested by Sturkell and others (2006). Inflation of the volcano will lead to dilation of the edifice, which can enhance permeability. This effect may be the explanation for the increased geothermal activity after 2001.

Finally, the use of a combined radar-altimeter and kinematic GPS has potential as an inexpensive alternative to laser altimeters. Although lacking the high accuracy and resolution of the laser altimeter, it is sufficient to map and monitor glacier surfaces such as that within the Katla caldera where variations in geothermal heat can lead to changes in excess of 5 metres.

\section{ACKNOWLEDGEMENTS}

Photographs and other valuable information from local pilot R. Ragnarsson are acknowledged. The airborne elevation profiling system was originally developed by ICAA electrical engineers G. Guðmundsson and B. Guðmundsson in 1999. Constructive reviews by $\mathrm{H}$. Rott and an anonymous reviewer improved the quality of this paper. The Katla monitoring is funded by the Icelandic Government while further data processing has been funded by EU-project VOLUME.

\section{REFERENCES}

Björnsson, H. 1975. Subglacial water reservoirs, jökulhlaups and volcanic eruptions. Jökull, 25, 1-14.

Björnsson, H. 2002. Subglacial lakes and jökulhlaups in Iceland. Global Planet. Change, 35(3-4), 255-271.

Björnsson, H. and M.T. Guðmundsson. 1993. Variations in the thermal output of the subglacial Grímsvötn caldera, Iceland. Geophys. Res. Lett., 20(19), 2127-2130.
Björnsson, H., F. Pálsson and M.T. Guðmundsson. 2000. Surface and bedrock topography of Mýrdalsjökull, Iceland: the Katla caldera, eruption sites and routes of jökulhlaups. Jökull, 49, 29-46.

Björnsson, H., F. Pálsson and H. Haraldsson. 2002. Mass balance of Vatnajökull (1991-2001) and Langjökull (1996-2001), Iceland. Jökull, 51, 75-78.

Einarsson, P. 2000. Atburðarás í tengslum við hlaup í Jökulsá á Sólheimasandi í júlí 1999 [Course of events leading to a jökulhaup in Jökulsá á Sólheimasandi in July 1999]. Geoscience Society of Iceland, February Meeting 2000, p. 12.

Elíasson, J., G. Larsen, M.T. Guðmundsson and F. Sigmundsson. 2006. Probabilistic model for eruptions and associated flood events in the Katla caldera, Iceland. Comput. Geosci., 10, 179-200.

Eythorsson, J. 1945. Um Kötlugjá og Mýrdalsjökul [On Katla and Mýrdalsjökull]. Náttúrufræðingurinn, 15, 145-174.

Guðmundsson, M.T. 2003. Melting of ice by magma-ice-water interactions during subglacial eruptions as an indicator of heat transfer in subaqueous eruptions. In: White, J.D. J.L., Smellie and D. Clague. Explosive subaqueous volcanism. American Geophysical Union, Geophysical Monograph 140, 61-72.

Guðmundsson, M.T. 2005. Subglacial volcanic activity in Iceland. In Caseldine, C.J., A. Russell, J. Hardardóttir and Ó. Knudsen, eds. Iceland: modern processes, past environments. Amsterdam, Elsevier, pp. 127-151.

Guðmundsson, M.T., F. Sigmundsson and H. Björnsson. 1997. Icevolcano interaction of the 1996 Gjálp subglacial eruption, Vatnajökull, Iceland. Nature, 389(6654), 954-957.

Guðmundsson, M.T., F. Sigmundsson, H. Björnsson and P. Högnadóttir. 2004. The 1996 eruption at Gjálp, Vatnajökull ice cap, Iceland: efficiency of heat transfer, ice deformation and subglacial water pressure. Bull. Volcanol., 66(1), 46-65.

Guðmundsson, S., M.T. Guðmundsson, H. Björnsson, F. Sigmundsson, H. Rott and J.M. Carstensen. 2002. Three-dimensional glacier surface motion maps at the Gjálp eruption site, Iceland, inferred from combining InSAR and other ice-displacement data. Ann. Glaciol., 34, 315-322.

Hoskuldsson, A. and R.S.J. Sparks. 1997. Thermodynamics and fluid dynamics of effusive subglacial eruptions. Bull. Volcanol., 59(3), 219-230.

Larsen, G. 2000. Holocene eruptions within the Katla volcanic system, south Iceland: characteristics and environmental impact. Jökull, 49, 1-28.

Major, J.J. and C.G. Newhall. 1989. Snow and ice perturbation during historical volcanic eruptions and the formation of lahars and floods. A global review. Bulletin Volcanologique: organe de la Section de Volcanologie de I'Union Géodésique et Géophysique Internationale, 52, 1-27.

Pierson, T.C., R.J. Janda, J.C. Thouret and C.A. Borrero. 1990. Perturbation and melting of snow and ice by the 13 November 1985 eruption of Nevado del Ruiz, Columbia, and subsequent mobilization, flow, and deposition of lahars. J. Volcan. Geotherm. Res., 41, 17-66. 
Pinel, V. and 6 others. 2007. Discriminating volcano deformation due to magma movements and variable surface loads: Application to deformation of the subglacial Katla subglacial volcano, Iceland. Geophys. J. Int., 169(1), 325-338.

Rist, S. 1957. Snjómæling á jöklum 1954 og 1955 [Snow survey on Icelandic glaciers 1954 and 1955.]. Jökull, 7, 33-36.

Sigurðsson, O., S. Zóphóníasson and E. Ísleifsson. 2000. Jökulhlaup úr Sólheimajökli 18. júlí 1999 [Jökulhlaup from Sólheimajökull 18 July 1999]. Jökull, 49, 75-80.

Sturkell, E. and 9 others. 2006. Volcano geodesy and magma dynamics in Iceland. J. Volcan. Geotherm. Res., 150, 14-34.
Thorarinsson, S. 1957. The jökulhlaup from the Katla area in 1955 compared with other jökulhlaups in Iceland. Jökull, 7, $21-25$.

Thorarinsson, S. 1974. Vötnin Stríð. Saga Skeiðarárhlaupa og Grímsvatnagosa [The swift flowing rivers. The history of Grímsvötn jökulhlaups and eruptions. Reykjavík, Menningarsjóður.

Tómasson, H. 1996. The jökulhlaup from Katla in 1918. Ann. Glaciol., 22, 249-254.

Tryggvason, E. 1960. Earthquakes, jökulhlaups and subglacial eruptions. Jökull, 10, 18-22. 